\title{
EVALUATION OF THE PRIVATE PARTICIPATION IN THE IMPLEMENTATION AND MANAGEMENT OF ECOTOURISM IN CAVERNAS DO PERUAÇU NATIONAL PARK, BRAZIL
}

\author{
PRISPEVEK ZASEBNIKOV PRI VZPOSTAVITVI IN UPRAVLJANJU \\ EKOTURIZMA V JAMAH NARODNEGA PARKA CAVERNAS DO \\ PERUAÇU, BRAZILIJA
}

\author{
Hugo Rodrigues de ARAUJO ${ }^{1}$, Heros Augusto Santos LOBO ${ }^{2}$ \\ \& Luiz Eduardo Panisset TRAVASSOS 3 ,*
}

\begin{abstract}
UDC 338.485.1:551.44(81)

Hugo Rodrigues de Araujo, Heros Augusto Santos Lobo \& Luiz Eduardo Panisset Travassos: Evaluation of the private participation in the implementation and management of ecotourism in cavernas do Peruaçu national park, Brazil

In the last two decades, Brazil has advanced in the creation of Natural Protected Areas (NPAs), reaching more than 17\% of its territory. However, the budget allocated for the effectiveness of NPAs is still insufficient, creating gaps that hinder these areas from fulfilling their purposes. The Cavernas do Peruaçu National Park (PNCP) was created in 1999. Its ecotourism infrastructure was conceived and built from 2011 to 2015 and opened to the public in 2017. The implementation of the PNCP differs from other NPAs under the responsibility of the federal government management in Brazil, since it involves private resources from companies with legal obligations to environmental compensation. In this context, a study on the PNCP was carried out, with primary and secondary data analysed. The research aimed at report the process of the PNCP implementation as well as presenting the current state of management and prospects for this Park. With the results obtained, it was possible to conclude that the experience of a partnership between the public power and the private initiative is a practical possibility for the implementation and management of ecotourism, expanding its socioeconomic sustainability and contributing to the goals of nature conservation.

Key words: national parks, ecotourism, natural heritage, archaeological sites.
\end{abstract}

Izvleček

UDK338.485.1:551.44(81)

Hugo Rodrigues de Araujo, Heros Augusto Santos Lobo \& Luiz Eduardo Panisset Travassos: Prispevek zasebnikov pri vzpostavitvi in upravljanju ekoturizma $v$ jamah narodnega parka Cavernas do Šeruaçu, Brazilija

Brazilija je v zadnjih dveh desetletjih razvijala program zaščitenih naravnih območij, ki danes zavzemajo $17 \%$ površine države. Vendar namenska proračunska sredstva namenjena zaščitenim območjem, ne zadoščajo za učinkovito upravljanje in izvajanje zaščite. Narodni park Cavernas do Peruaçu (NPCP) je bil ustanovljen leta 1995. Infrastruktura, zasnovana na ekološkem pristopu, je bila zgrajena med leti 2011 in 2015 in leta 2017 odprta za javnost. NPCP je izjema med zaščitenimi območji v upravljanju brazilske vlade, saj prejema tudi sredstva zasebnih podjetij, ki so zakonsko obvezana dajatev okoljskega nadomestila. $\mathrm{V}$ raziskavi poročamo o razvoju, upravljanju in perspektivah parka. Pokažemo, da je javno zasebno partnerstvo mogoče in da lahko bistveno izboljša možnosti učinkovitega upravljanja, utrjuje socialno-ekonomsko vzdržnost območja in prispeva k boljšemu varovanju narave.

Ključne besede: narodni parki, ekoturizem, naravna dediščina, arheološka najdišča.

${ }^{1}$ Hugo Rodrigues de Araujo, Institute of Geography and Spatial Planning (IGOT) of the University of Lisbon, Rua Branca Edmée Marques, 1600-276 Lisbon, Portugal, e-mail: hugo.araujo@campus.ul.pt

${ }^{2}$ Heros Augusto Santos Lobo, Federal University of São Carlos (UFSCar), Rodovia Washington Luís, s/n, São Carlos - SP, $13565-$ 905, Brazil, e-mail: heroslobo@hotmail.com

${ }^{3}$ Luiz Eduardo Panisset Travassos*, CNPq Research Productivity Fellow (PQ-2), Pontifical Catholic University of Minas Gerais, Graduate Program in Geography. Av. Dom José Gaspar, 500 Coração Eucarístico, Belo Horizonte, MG, 30535-901, Brazil, e-mail: luizepanisset@gmail.com

* Corresponding Author

Received/Prejeto: 06.02.2019 


\section{INTRODUCTION}

Brazil is one of the countries with the highest diversity of endemic species of animals and plants which are not found in nature in other parts of the world (Myers et al. 2000). The Brazilian territory is also richly diverse in rocks, minerals, soils and other geological and geomorphological features (Silva 2008), and whose its biodiversity allows one to understand the country's natural heritage.

Among the measures taken by public authorities in Brazil to protect the natural heritage, one can point out the creation of Natural Protected Areas (NPAs) (Rylands \& Brandon 2005). NPAs are territorial portions delimited and managed to conserve natural heritage, which include biotic and abiotic elements (Medeiros et al. 2004). According to the Convention on Biological Diversity, in addition to the fundamental purpose of nature conservation, the creation of protected areas should also focus on the sustainable use of its components and the fair and equitable sharing of the benefits of conservation (Anaya \& Espírito Santo 2018). Thus, ecotourism stands out among the possibilities of trying to achieve these objectives (Watson et al. 2014).

In Brazil, most of the NPAs are public domains, being the management responsibility of Federal, State and Municipal bodies linked to the environment (Oliveira et al. 2017). Over time, the creation of new NPAs has outpaced the governments' ability to provide adequate financial resources. As a result, new management models that allow a more entrepreneurial approach, with greater financial independence for management have started (Pegas \& Castle 2014).
However, unlike other countries such as the United States and South Africa, little attention has been paid in Brazil to private partnerships and concessions for the management of ecotourism in NPAs, predominantly due to the political options of concentrating power in the State (Wilson et al. 2009).

In this context, the objective of this article is to describe and analyse one of the exceptional cases in the country, through private participation in the implementation and management of ecotourism in the Cavernas do Peruaçu National Park (PNCP). Among the exceptions, there is considerable active participation of organised civil society and private resources in their processes of land regularisation, planning and management.

For this paper, documentary research was developed, complemented with field studies. The documentary analysis focused on the commitments made by the Brazilian Institute for the Environment and Renewable Natural Resources (IBAMA) and Fiat Automóveis S.A. (Brazil 1997; 2002), in the management plan of the National Park (Brazil 2005), in its executive implementation projects (Instituto Ekos Brasil n/a; Brazil 2010) and studies and reports produced on the Park. The field survey involved personal interviews with the PNCP manager using a semi-structured questionnaire with open questions. Besides, the authors' involvement with the PNCP has taken place since 2008, which has enabled the participation and monitoring of several phases of the implementation and start of ecotourism management in the National Park.

\section{THEORETICAL BASIS}

The question of environmental preservation and conservation in Brazil dates back to a time when the country was still a colony of Portugal. The historical records indicate that the Portuguese crown has developed some initiatives to ensure control over the management of specific natural resources, such as wood and water, as was already practised in European countries (Medeiros 2006).

In 1872, the creation of Yellowstone National Park in the United States and its perpetuation as a model of "Park" as a category of NPA (Dudley 2008), opened space for future discussion and mobilisation for the creation of parks in Brazil. Years after the proclamation of the Republic (1889), in 1937, the first Brazilian park, the Itatiaia National Park, was created in the state of Rio de Janeiro (Oliveira et al. 2017).

Over time, the evolution of Brazilian legislation has given rise to other forms of protected natural areas, as well as the expansion of the number of parks managed at the national, regional or local level. At present, Brazil has 425 parks, with approximately 36 million hectares, involving all its biomes. This total ensures the protection of $4.22 \%$ of the continental area and $0.11 \%$ of the country's marine area (Brazil 2019).

However, many of the Brazilian parks are not yet fully implemented (Pegas \& Castle 2014). According to Drummond, Franco and Oliveira (2010), nature conservation depends not only on the creation of new NPAs 
but also on the consolidation of existing ones. In 2012, the World Wide Fund for Nature (WWF) published a study that evaluated the effectiveness of management of the Brazilian National Parks (NPAs). In 2006, 56.7\% of NPAs were vulnerable, and in 2010 this percentage decreased to $51.3 \%$. The results showed that the vulnerability of Federal NPAs had diminished and that this happened due to around $32 \%$ increase of the financial resources directed to these areas. It also reflected about $31 \%$ increase of human resources allocation in the same period. Although NPAs have undergone progress in the management process, these factors have not significantly influenced the overall result on management effectiveness which, according to that report, increased from $40.1 \%$ to only $48.1 \%$ (WWF-Brazil \& Instituto Chico Mendes de Conservação da Biodiversidade [ICMBio] 2012).

In Brazil, many NPAs are not fulfilling their primary role of conservation, due to the lack of financial and human resources, incomplete land regulation, the presence of conflicting human activities in and around these areas, the political instability of the environmental agencies, among others (Anaya \& Espírito-Santo
2018). Insufficient infrastructure (e.g., lack of administrative bases and visitor centres, few or no equipment, and weak inspection system) are also obstacles to the consolidation of NPAs. A large number of protected areas also face threats from urban sprawling and infrastructure projects such as roads and dam constructions (Bechara 2009).

The fragility of NPA management is not limited to the lack of the official capacity to provide adequate management and protection tools, but it is also due to the lack of financial and administrative autonomy of the management organisations (Lima et al. 2005). When changes of priority in the executive budget occur, the whole system collapses because of the exclusive dependence on public resources. Therefore, one can observe the interruption or reduction of resources transferring to the NPAs (Spenceley et al. 2017; Pellin et al. 2007; Rocktaeschel 2006).

NAP managers not only in Brazil but throughout the world, are being pressured to become more creative, innovative, flexible and enterprising (Eagles et al. 2002; Saporiti 2006). After all, these entities often do not have sufficient staff and funds to fulfil their primary respon-

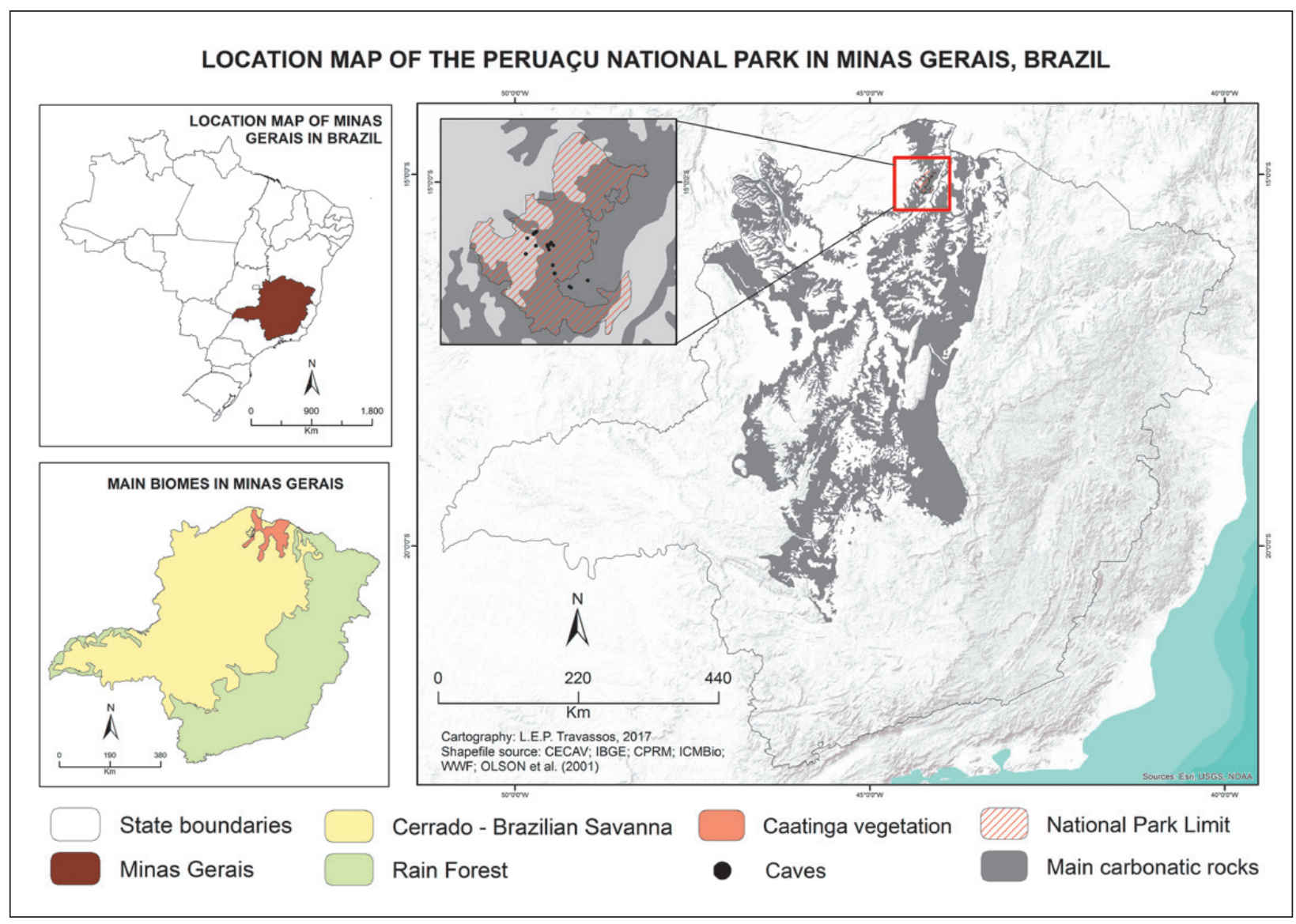

Fig. 1: Location map of the Cavernas do Peruaçu National Park in Brazil. 
sibility, which is to protect natural resources in NPAs and to provide quality services to visitors (Castro 2018; Rocktaeschel 2004).

The services demanded by NPA visitors, such as food, lodging and ecotourism activities can be offered through partnerships with the private initiative (Penceley et al. 2017). The offer of quality services and pleasant experiences are among the factors that can boost visitation and interest in NPAs (Castro 2018). These partnerships are usually carried out with private companies but may involve community associations and non-governmental organisations (NGOs) (Spenceley et al. 2017). The supply of services needs to be observed more carefully regarding ecotourism products. These must meet not only the visitors' wishes, but also make possible the valorisation of the local culture, the generation of income for the receiving community and the conservation of the visited environment (Brazil 1994).

Good examples are reported around the world on income generation initiatives in NPAs (Marino \& Pellegrino 2018; Pfueller et al. 2011; Wilson et al. 2009). In Peru, for example, a successful case of a public-private alliance has been reported promoting conservation and, at the same time, ecotourism, in the Tambopata Nation- al Reserve. In 2006, a concession contract signed between an ecotourism company and the National Service of Natural Areas Protected by the State (SERNANP) allowed to access and use a small area of the Reserve. This contract may be renewable every 20 years and includes the development of scientific research, the generation of direct and indirect jobs and training, always prioritizing the recruitment of personnel from indigenous communities in the region, and the promotion of ecotourism by disseminating the value of biological diversity and cultural heritage of the Tambopata National Reserve (Leung et al. 2018). As noted, partnerships with the private sector can stimulate innovation, drive conservation initiatives, foster collaborative decision-making, and promote ecotourism (Whitelaw et al. 2014).

Consequently, partnerships between government and private enterprise are increasingly seen as a possible solution for managers to reduce the need for public subsidies (Wyman et al. 2011; Buckley 2004). Also, management entities would be better able to manage daily issues of environmental preservation and conservation, such as fire control, wildflower management, trail maintenance, and other functions (Eagles et al. 2002; Buckley 2004).

\section{METHODS}

The PNCP is located in the northern region of Minas Gerais State and spreads throughout the municipalities of Itacarambi, Januária, and São João das Missões (Fig. 1). The Park, created by a Federal Law in 1999, has an area of 56,800 hectares (Brasil 2005) in an important Brazilian karst area.

In geological terms, the investigated area is part of the geotectonic unit of the São Francisco Supergroup and the Bambuí Group, composed of rock compartments of several ages. The sedimentation of carbonates occurred from 900 to 600 million years ago, in an epicontinental sea of shallow waters in the irregular and impermeable crystalline base that allowed the development of the Brazilian carbonate platform (Auler 1994; Piló 1998; Alkmim \& Martins-Neto 2001; Travassos \& Kohler 2009). The units of the Bambuí Group cover approximately the extension of the current basin of the São Francisco River and, according to Piló and Rubbioli (2002), the region is developed in the São Francisco Karst Plateau located between the altitudes of 750 to $500 \mathrm{~m}$.

On a global scale, according to the KöeppenGeiger classification, the regional climate is classified as Aw, wet tropical with dry winters. Maximum temperatures can be as high as $38^{\circ} \mathrm{C}$. Minimum temperatures can reach $12^{\circ} \mathrm{C}$ with annual averages of $26^{\circ} \mathrm{C}$. The pluviometry data show that the local climate is tropical with two well defined seasons. Rains are scarce and irregular, mainly concentrated in the summer, occurring from October to February. The annual average rainfall reaches a $900 \mathrm{~mm}$ (Serafini 2005).

The main drainage basin is the Peruaçu river, a tributary of the São Francisco, which is one of the most important Brazilian rivers. The drainage network presents perennial and intermittent watercourses. When captured to an underground system, some of them stop flowing on the surface at some times during the year, as it is common in most karst areas.

The original vegetation is a transition between two crucial morphoclimatic biomes: the Cerrado and the Caatinga (Fernandes 2007; Ab'Saber 1977). However, during fieldwork, it is possible to identify occurrences of Dry Forests, typical phytophysiognomies of the Rain Forest. During the rainy season, the landscape is predominantly green; in the dry season, however, the trees are entirely leafless, giving rise to a different environ- 


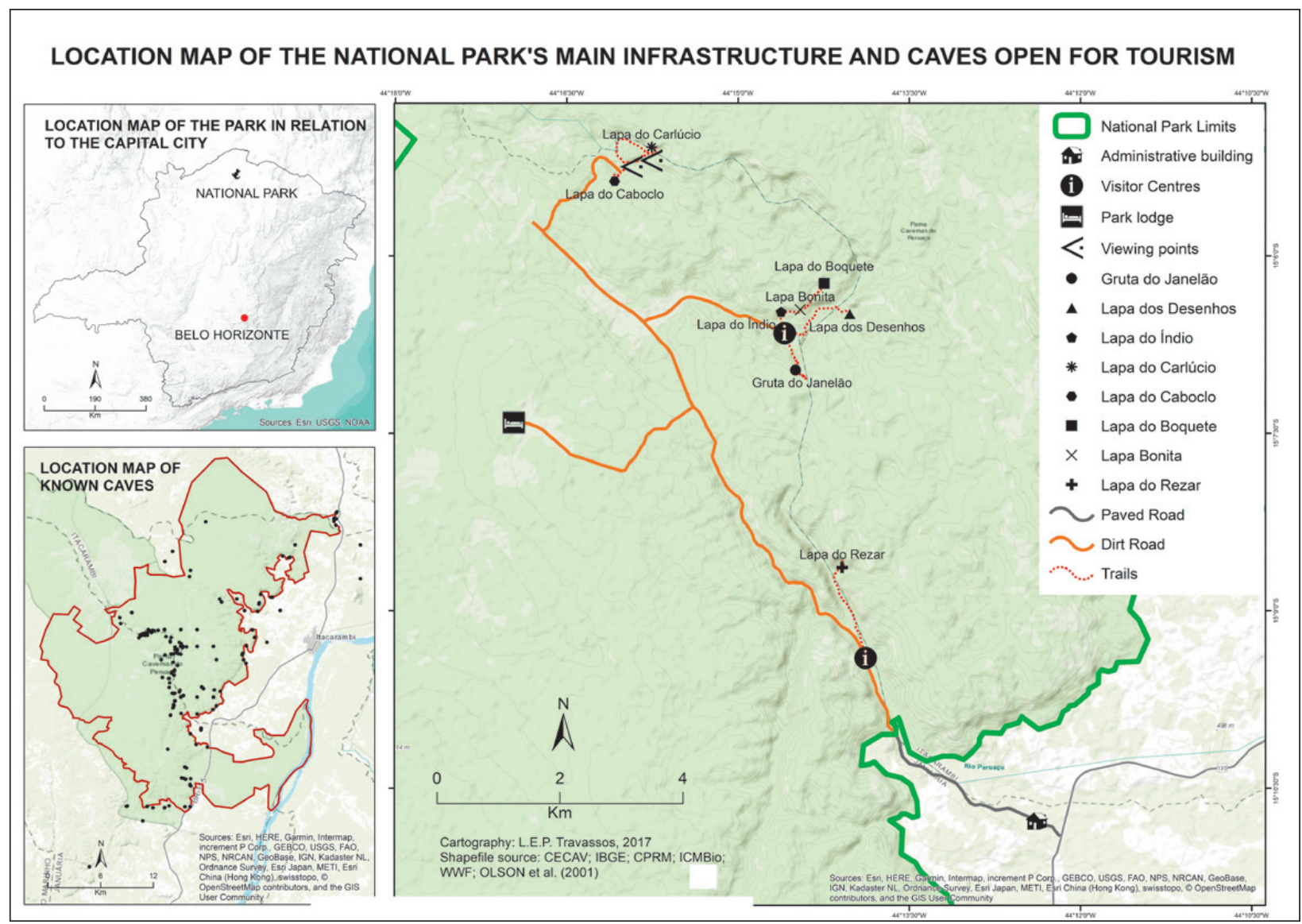

Fig. 2: Map showing the location of the National Park's central infrastructure and caves open for ecotourism.

ment at this time of the year. The Park also stands out for its caves and archaeological treasures. There are more than 180 registered caves and numerous archaeological sites with cave paintings dating from 9 to 12,000 BP. Due to its historical, archaeological and natural values, the PNCP is a karst area in Brazil mentioned in an IUCN study as having the universal requirements to be considered a World Heritage Site (Williams 2008). This condition has been neglected by local authorities for years, despite numerous experts reinforcing it and the studies that mentioned its potential (e.g., Piló 1997; Piló \& Rubbioli 2002; Lobo \& Boggiani 2013). It was only in 2017 that the government of Minas Gerais state, in partnership with local governments and the organized civil society, initiated a movement which is intended to put pressure on the Federal Government to make more efforts to applying for the recognition of the PNCP region as a UNESCO Natural and Cultural Heritage (Dutra 2017).

The infrastructure of the Park is still in the process of being concluded. To date, one can see a research support centre, visitors centres, the improvement of access roads, the implementation of visitation itineraries, and facilitating equipment. The PNCP offers six ecotourist routes (Fig. 2): 1. Lapa do Boquete (Fig. 3a); 2. Lapa do Índio and Lapa Bonita (Fig. 3b); 3. Gruta do Janelão (Fig. 3c); 4. Lapa dos Desenhos (Fig. 3d); 5. Lapa do Caboclo and Lapa do Carlúcio (Fig. 3e); 6. Lapa do Rezar (Fig. 3f).

The implementation of the ecotourist routes considered the various conditions of environmental fragility of the terrain and vegetation, different aspects related to the intensity of visitation and different degrees of danger and risk of accidents. The materials and construction techniques used in the process of implantation of the visitation infrastructure (Fig. 4) based on principles of minimum impact, following general guidelines established in the works of Gillieson (2011) and Hildreth-Werker and Werker (2006).

Since the trails and protective structures of the archaeological sites and caves completed, the PNCP experimentally opened for visits since April 2017. The visits must be scheduled previously with the management of the PNCP. It is necessary to hire a guide for groups of up to eight people to access the attractions of the Park. Chico Mendes Institute for Biodiversity Conservation 


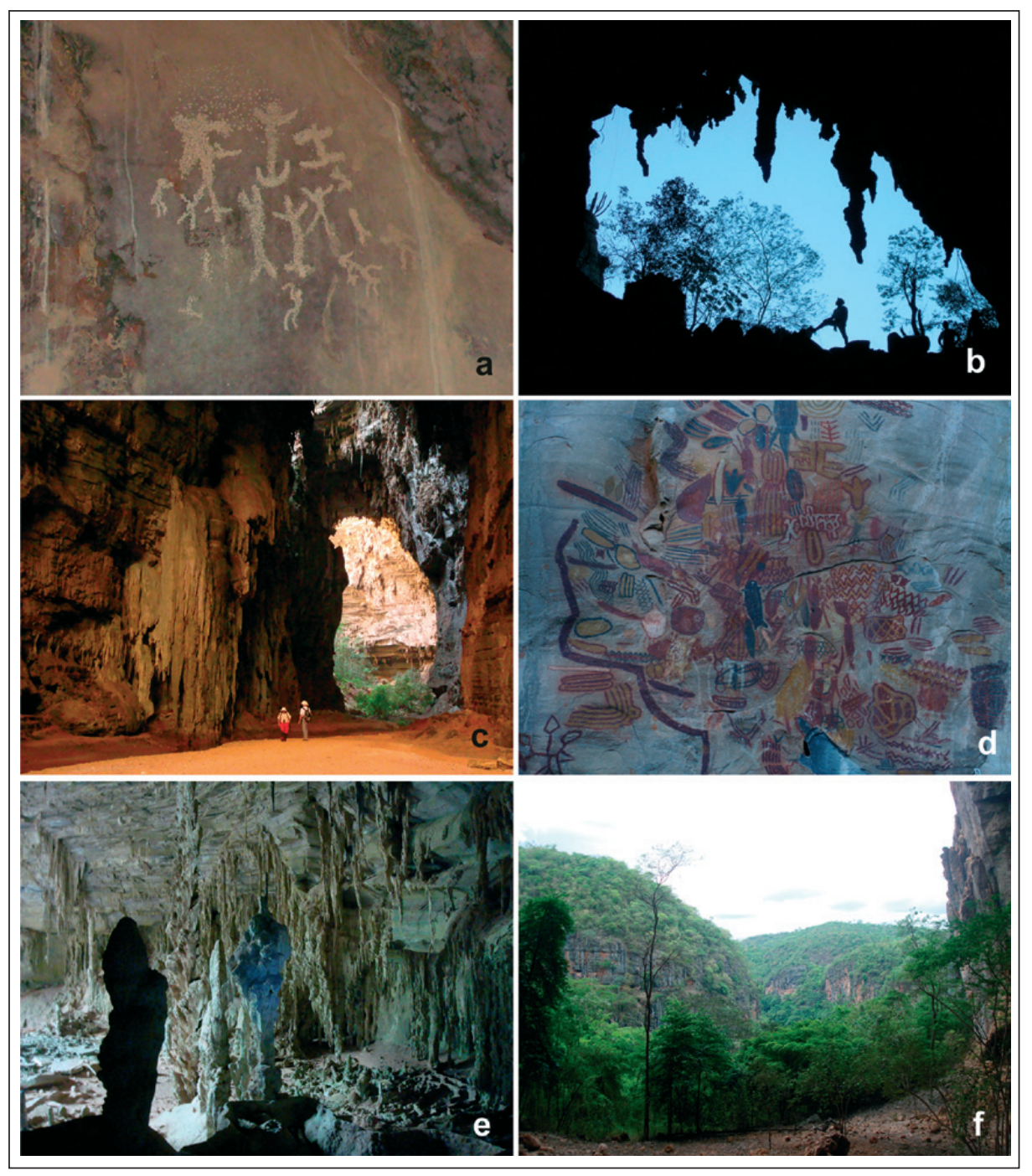

Fig. 3: Main tourist attractions in the PNCP.
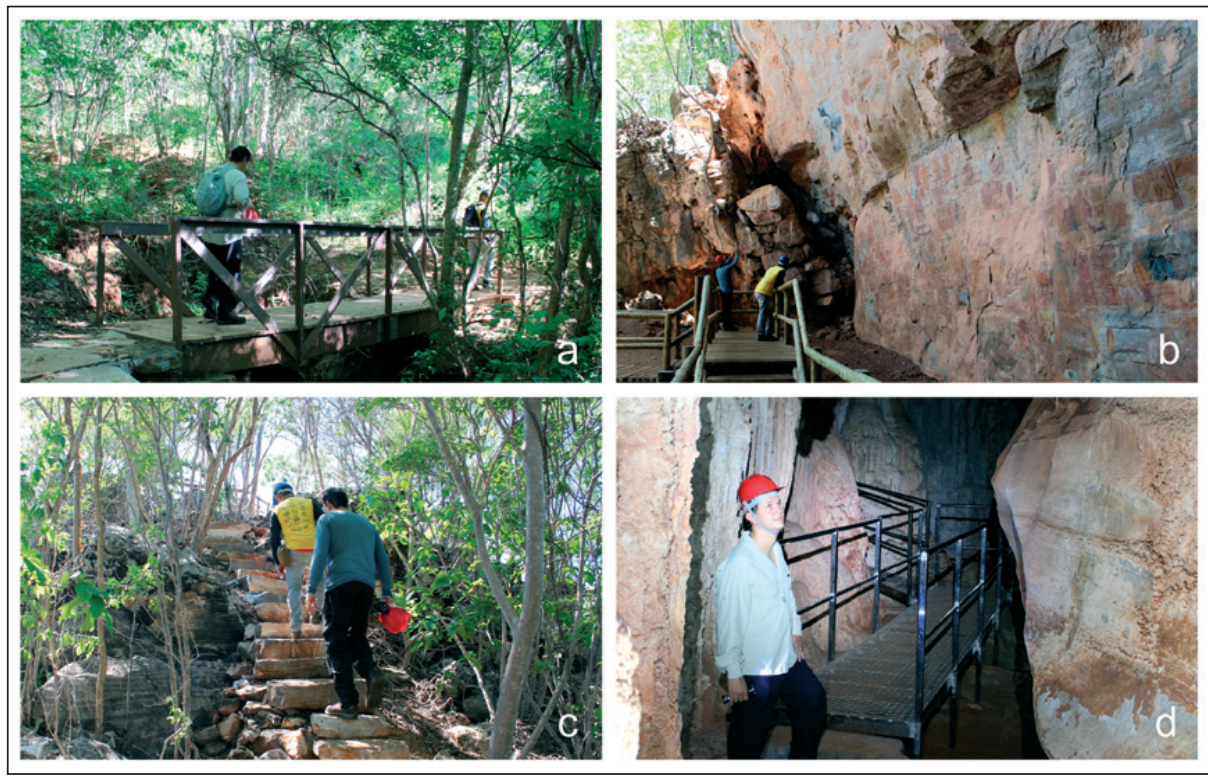

Fig. 4: Infrastructure works carried out at the PNCP for the implementation of the visitation itineraries. In $a$ and $b$, external structures. In $c$, deck for visualisation of cave paintings. In $d$, the metallic structure inside a cave. 
(ICMBio - the federal park management agency), in partnership with the organised civil society, has offered two training courses for the local guides. The 41 participants in these courses are accredited to conduct visits within the PNCP.
In an initial experimental phase before the formal opening to the public, the Park received about 600 visitors in 2014 and 3,000 visitors in 2015. Considering that the advertisement and other promoting actions are still incipient, this is quite a significant increase.

\section{RESULTS AND DISCUSSION}

\section{THE ALLOCATION OF PRIVATE RESOURCES FOR PNCP IMPLEMENTATION}

According to the Brazilian legislation regarding NPAs (Brasil 2000), part of the resources collected in each protected area should be applied to the implementation, maintenance and management of the area itself, as well as contribute to land regularisation and maintenance of the protected areas system (Sousa et al. 2011).

However, at present, NPA managers are required to deposit the funds raised into a single state account, and usually, these financial resources tend not to return to their source. Thus, although it is possible to have projects of income generation developed within some NPAs, it is still necessary to overcome many bureaucratic difficulties related to public management patterns (Rylands \& Brandon 2005). The budget allocated to NPAs in Brazil has never been sufficient, preventing them from fulfilling the purposes for which they were created (Bechara 2009). This neglect creates significant obstacles to these projects consolidation, especially concerning their legal and structural aspects, such as land regularisation, elaboration of management plans and the installation of the necessary infrastructure for its working effectively as a National Park (Pellin et al. 2007).

Because of that, alternative paths are often sought to enable the operation of NPAs in Brazil. In the case of the PNCP, the necessary financial resources were obtained through a Term of Conduct Adjustment (Termo de Ajustamento de Conduta - TAC) signed between the Federal Public Prosecutor Service (PUBLIC MINISTRY), the Brazilian Institute for the Environment and Renewable Natural Resources (IBAMA) and a multinational automobile manufacturer with a factory established in Brazil (Brasil 1997).

As mentioned before, in 1995, the IBAMA assessed that the company failed to comply with environmental protection standards. After technical and legal analyses, the company was condemned for the emission of pollutants from one of its vehicle models manufactured in Brazil. The Notice of Infringement based on non-compliance with Brazilian environmental legislation for the production and sale of 429,928 vehicles of this same model, from January 1, 1993, to June 30, 1995. The company was fined but reached an agreement between the parties involved in this situation, which generated alternative forms of payment of the fine, instead of doing so with financial resources (Mungai 2008). Among the responsibilities assumed, the company defined the implementation of the PNCP for efficient use as its commitment. The company was responsible for purchasing a total area of 6,000 ha for the implementation of the PNCP and donating it to the Federal Government within six months. In addition to this measure, and within the six months after the land tenure, the company would have to prepare the management plan of the total area of 56,800 ha of the Park to be implemented and submit it to the approval of the PUBLIC MINISTRY, as well as bear with the infrastructure costs required to create the Park (Brasil 2002).

According to Mungai (2008), a service agreement was signed in September 2002 by the IBAMA, the car factory and consulting companies, in order to prepare the management plan. The work began in December of that same year and finished in May 2005. On December 17, 2004, it was created the Advisory Council of the PNCP to assure the participation of surrounding communities in the planning and decision-making processes. Only after the approval of the management plan, which occurred in December 2005, it was possible to begin works of infrastructure.

In March 2007, a new meeting occurred for the parties to sign an addendum to the condemned company to comply with its obligations with the Public Ministry. At the time, the following works were defined as mandatory: water supply and sanitary waste treatment, remodelling and construction of buildings, the improvement of roads, implementation of tourist itineraries with adequate trails, installation of access infrastructure and signs in caves and archaeological sites. The schedule agreed between the parties predicted the PNCP should be ready to open until to March 2009 (Mungai 2008). 
However, another addendum to the TAC was signed on June 24, 2010, to approve the "Detailed Plan". Again, a document specified the activities to be developed by the fined company in the park during the infrastructure implementation phase and what equipment should be purchased then as well as which schedule should be followed, with the start and the completion deadlines for the work. In this same document, it was agreed that the domain of the property, with a total area of 10,356 ha, located in the limits of the Park, acquired by the company, was to be transferred to Chico Mendes Institute of Biodiversity Conservation (ICMBio), a governmental agency created in 2007 when the government restructured the IBAMA. In addition to this property, the company had to acquire and transfer other properties as already planned before. It was agreed that full compliance with the obligations assumed and agreed upon could not unreasonably exceed a 3-year term. After the deadline was respected and the obligations fully complied with, ICMBio and the Public Ministry would grant the fined company the discharge of the obligations outlined in the Terms of Commitment dated of October 14, 1997, and June 20, 2002.

Despite the deadlines established, infrastructure works were concluded only in 2017. Several delays occurred in this period of time due to factors such as weather conditions, delays in project approvals, recurrent revisions of approved projects, changes in the expected prices, the need for adjustments within the condemned company for the allocation of financial resources, popular mobilizations due to disagreement with the way services were executed, among other items. In April 2017, it occurred the last stage of the Park implementation, which corresponded to the installation of signs in all opened trails.

One can undoubtedly notice that the slowness of the process of development of the Park turned into some disbelief and rejection from residents since many expectations of improving living conditions and the maintenance of resident populations around the PNCP were frustrated (Mungai 2008), as it often happens with most Brazilian NPAs for public use (Medeiros 2006).

On the other hand, the private financing for the implementation of the PNCP is positively recognised by the unit manager, since the Park would probably not be in the current stage of development without it. Other Brazilian parks created in the same period of the PNCP, to date, are closed with no prospect of resources, neither for land regularisation nor for the execution of infrastructure works (Brasil 2018).

Given the fact of how insufficient is the budget allocated to the NPAs, it understandable that private resources derived from environmental compensation may become a more efficient way of implementing NPAs. According to article 36 of the Brazilian legislation on NPAs (Brazil 2000), in the cases of enterprises that cause significant environmental impact, as considered by the competent environmental agency, the entrepreneur is obliged to support the implementation and maintenance of an NPA of full protection of nature. Brazilian Parks are in this perspective (Brazil 2000).

Nevertheless, it is essential to observe whether the environmental compensation policy is not used as a greenwashing means for the felony company.

In the TAC signed between the parties involved in the case of the PNCP, the company was allowed to develop environmental education measures to publicize the creation and implementation of the Park together with newspapers, magazines, television and other media, as well as to raise the awareness of the population for the importance of environmental preservation (Brasil 2002). Although these initiatives are commendable due to their objectives, one can think that authorities in charge take up a position that nullifies the company's attempt to use the repercussion of such actions in their favour, considering that their actions in this process are not spontaneous, but a compensation lawsuit result for previously caused damage.

\section{THE COOPERATION AGREEMENT FOR INTEGRATED AND PARTICIPATORY MANAGEMENT OF THE ECOTOURISM IN THE PNCP}

Once the fined company complied with its obligations to the PUBLIC MINISTRY and ICMBio, a new phase of the process of consolidating the implementation of the tourist use of the PNCP began. The current stage involves maintenance, inspection, management and research, among other demands.

Considering the usual neglect of the Brazilian government usual neglet of the NPAs (Oliveira 2017; Rylands \& Brandon 2005; Lima et al. 2005), even before the completion of the tourist infrastructure works of the PNCP, ICMBio foresaw the need to find ways to guarantee the maintenance of the Park without relying exclusively on public resources. In addition to guaranteeing minimum financial resources for the Park, it was also necessary to adopt a management structure that can ensure agility and efficiency in the allocation of resources.

Article 30 of the Brazilian legislation on protected areas states that NPAs can be managed by civil society organisations of public interest (OSCIP, in Brazil) with similar objectives to those of the unit itself. This process can be carried out through an instrument signed with the board responsible for its management (Brazil 2000). This possibility does not exempt the environ- 
mental agency from its responsibilities with the integrity of the NPA (Sousa et al. 2011). Some NPAs have had both formal and informal partnerships for many years. There are countless cases of success and quite innovative experiences, especially in the Amazon (Kalikoski et al. 2009).

From this perspective, in December 2016, ICMBio started a process to select proposals from civil society organisations aiming at establishing a partnership in the management of the PNCP, to support the implementation of the tourist use program, foreseen in the management plan (Brazil 2016a).

The chosen organisation was an OSCIP that participated in the elaboration of the management plan and coordinated the works of implementation of tourist infrastructure of the Park. The cooperation agreement is valid for five years, but non-extendable. The goals provided in the Work Plan for the OSCIP are, as follows: 1) Improvement in the reception, safety and satisfaction of the visitor, 2) Maintenance and repairs of the buildings and visitor support structures, 3) Support for logistics and administrative activities related to visitation, 4) Support for monitoring and protection activities, 5) Strengthening the PNCP's relationship with its surroundings, 6) Evaluation, monitoring and subsidies to improve the management plan of the PNCP, 7) Assist in the recovery of the Peruaçu River basin, and 8) Promotion and dissemination of the historical, cultural and environmental heritage of the PNCP (Brasil 2016a).

The agreement does not provide for the transfer of financial resources to this OSCIP, and they must use its funds, or those obtained from other external sources, to carry out the assigned activities. ICMBio will be in charge of constituting a committee that will be responsible for monitoring and evaluating the work developed by this organisation (Brasil 2016b). The OSCIP has already been developing actions to obtain resources, such as the creation of the Peruaçu Fund, the sale of souvenirs (e.g., t-shirts, stickers and books) with the brand and visual identity of the Park and the search for sponsoring companies. They are also investing in improving the park's relationship with international conservation organisations (IUCN), the United Nations Educational, Scientific and Cultural Organization (UNESCO), expand its scope and effectiveness.

Yet, some challenges still prevail. At present, the Park has only two active employees, and three outsourcers who take care of all the administrative and executive activities in more than 56,000 ha of extension out of the almost 100 people planned initially in its management plan (Brazil 2005). This way, according to the park manager, it is not possible to plan and manage the park's tourist use program ideally. Therefore, one can understand that the implementation of the partnership between ICMBio and the selected OSCIP will create conditions for more consistent advances in the consolidation of the PNCP.

This new structure could stimulate partnerships with the civil society to strengthen the management needs of the Park (Pfueller et al. 2011; Saporiti 2006; Rocktaeschel 2006). However, it is necessary to be careful in order to avoid that these concessions for services and bids for the exploitation of the Park lead to favouring external agents to the detriment of residents (Anaya \& Espírito-Santo 2018; Wyman et al. 2011). The development of the public use of the Parks should prioritise the action and leadership of the local communities so that it can significantly contribute to the improvement of the quality of life of the surrounding communities and municipalities (Spenceley et al. 2017).

\section{CONCLUSIONS}

This study presented the general context of Parks in Brazil - one of the possibilities for the natural protected areas that exist in the country. In most cases, NPAs are created without proper planning, preventing them from meeting the conservation of nature objectives besides not promoting regional development.

Several protected areas were created a long time ago and remain closed, waiting for public resources for land regularisation, elaboration of management plan and execution of infrastructure works. Since up to now no real strategy has been established for the implementation and the maintenance of NPAs in processes simi- lar to those presented. The TAC signed between the parties involved in the implementation of the PNCP can become a reference for other NPAs in Brazil.

The cooperation agreement in the management of the Park, signed between the managing board and a civil society organisation, can be considered as one of the viable solution possibilities for the various bureaucratic, administrative and financial difficulties of the NPA public management in this country.

Governments play an essential role in maintaining and managing NPAs, but when it comes to ecotourism activities, management entities tend to be restricted to 
their ability to innovate and respond to changing consumer demands (Eagles et al. 2002). That is one of the main reasons governments are increasingly favouring private concessions to manage the public use of NPAs (Pfueller et al. 2011).

The creation of NPAs without the prospect of implementing them should be avoided, as it provokes frustrating expectations, expropriation without compensation, economic and cultural destabilisation, culminating in regional dissatisfaction as well as the deterioration of the image of management entities and the protected area for the local communities (Drummond et al. 2010).

In the case of PNCP, community expectations should have been better managed through the definition of realistic plans and targets. The slowness of the process of opening the PNCP and the lack of transparency regarding the reasons for the delays over the years disappointed local people. After the creation of the Park, residents were prohibited from continuing to invest in traditional economic activities, such as agriculture and livestock. They were motivated by the idea that the protected area would receive a large number of visitors, and consequently would generate income and jobs in the region, improving life quality. Residents invested more significant ventures such as restaurants and hostels expecting to serve the possible growing number of visitors.

Given the importance of the Brazilian territory for the conservation of biodiversity (Myers et al. 2000) and geodiversity (Piranha et al. 2011) in the world, it is essential to maintain a well-managed system of NPAs. Only if these areas effectively fulfil their roles will the maintenance of rich natural diversity that the country harbours are guaranteed and society enjoy the economic and social benefits that these spaces can provide. Moreover, it is essential that areas with universal attributes, such as the PNCP region, be specially addressed by the Brazilian authorities. The first necessary step would be the attempt to register it as a UNESCO World Heritage Site, as demonstrated in previous studies (Williams 2008) and desired by the stakeholders involved with the Park management.

In this sense, the results of this study may be an essential tool to sensitise decision-makers, both regarding the importance of creating NPAs and the need for their implementation and maintenance. In order to consolidate these protected areas, other agents - besides the governments - must be engaged, not only to compensate for possible impacts and damages that have been caused but also to allow the broad involvement of society in the management process.

\section{ACKNOWLEDGEMENT}

This work was supported by the Coordination of Im- provement of Higher-Level Personnel-CAPES, Brazil, which granted scholarship to the first author.

\section{REFERENCES}

Ab’saber, A., 1977: Os domínios morfoclimáticos na América do Sul: Primeira aproximação.- Geomorfologia, 52, 1-21.

Alkmim, F. F. \& M. A. Martins-Neto, 2001: A bacia intracratônica do São Francisco: arcabouço estrutural e cenários evolutivos. In: C. P. Pinto \& M. A Martins-Neto (eds.). Bacia do São Francisco Geologia e Recursos Naturais. S.B.G, pp.09-30, Belo Horizonte.

Anaya, F., \& M. Espírito-Santo, 2018: Protected areas and territorial exclusion of traditional communities: analyzing the social impacts of environmental compensation strategies in Brazil.- Ecology and Society, 23(1):8. https://doi.org/10.5751/ES-09850-230108
Auler, A., 1994: Hydrogeological and hydrochemical characterization of the Matozinhos.- MSc Thesis. Western Kentucky University, pp.110.

Bechara, E., 2009: Licenciamento e compensação ambiental na Lei do Sistema Nacional das Unidades de Conservação (SNUC).- Atlas, pp. 295,São Paulo.

Brazil. Ministério da Indústria, do Comércio, do Turismo, \& Brazil. Ministério do Meio Ambiente, 1994: Diretrizes para uma política nacional de ecoturismo. EMBRATUR/IBAMA.

Brazil, 1997: Procedimento Administrativo Civil N. 08112.000968/97-41 Termo de compromisso que celebram o Ministério Público Federal e a Fiat Automó- 
veis S.A., objetivando a adoção de medidas que visem à melhoria da qualidade do meio ambiente.

Brazil, 2000: SNUC - Sistema Nacional de Unidades de Conservação da Natureza. Ministério do Meio Ambiente

Brazil, 2002: Procedimento Administrativo Civil N. 02001.006916/01-25 Termo de compromisso que celebram o IBAMA e a Fiat Automóveis S.A. com interveniência do Ministério Público Federal, objetivando a regularização fundiária, elaboração do plano de manejo e implementação do Parque Nacional Cavernas do Peruaçu.

Brazil, 2005: Plano de Manejo do Parque Nacional Cavernas do Peruaçu. Ministério do Meio Ambiente, pp. 146, Brasília.

Brazil, 2010: Projetos dos Roteiros de Trilhas do Parque Nacional Cavernas do Peruaçu. Ministério do Meio Ambiente. Instituto Brasileiro do Meio Ambiente e dos Recursos Naturais Renováveis.

Brazil, 2016a: Edital de chamamento público N. 01/2016. O ICMBio torna público a abertura do processo de seleção de propostas de organizações visando a cooperação mútua para gestão do Parque Nacional Cavernas do Peruaçu. Ministério do Meio Ambiente. Instituto Chico Mendes de Conservação da Biodiversidade.

Brazil, 2016b: Acordo de cooperação que celebram o ICMBio - Parque Nacional Cavernas do Peruaçu e o Instituto Ekos, com o objetivo de cooperação mútua para a gestão do Parque Nacional Cavernas do Peruaçu. Ministério do Meio Ambiente. Instituto Chico Mendes de Conservação da Biodiversidade.

Brazil, 2019: Cadastro nacional de unidades de conservação. Available from: http://www.mma.gov.br/areas-protegidas/cadastro-nacional-de-ucs/consultagerar-relatorio-de-uc [Accessed 4rd January 2019].

Buckley, R., 2004: Innovative funding mechanisms for visitor infrastructure in Australian National Parks.In: Griffin, T. (ed.) A natural partnership: Making national parks a tourism priority. Sustainable Tourism CRC, Sydney.

Castro, E., 2018: Changing a Brazilian Protected Areas Paradigm: Why Public Use is Not Just Optional.Journal of Park \& Recreation Administration, 36, 129-140. https://doi.org/10.18666/JPRA-2018-V36-I3-8409

Companhia de Desenvolvimento Econômico de Minas Gerais - CODEMIG., 2015: Mapa Geológico de Januária. 1:100.000.- Belo Horizonte.

Dudley, N., 2008: Guidelines for applying protected area management categories.- IUCN, pp. 86, Gland.

Dutra, M., 2017: Iniciada campanha PARNA Cavernas do Peruaçu como Patrimônio da Humanidade.SBE Notícias, 362, 2.

Drummond, J., Franco, J. \& D. Oliveira, 2010: Uma análise sobre a história e a situação das unidades de conservação no Brasil. In: Ganem, R. (org.) Conservação da biodiversidade: legislação e políticas públicas.- Edições Câmara, pp. 341-385, Brasília.

Eagles, P.F., McCool, S.F., D. Haynes, 2002: Sustainable Tourism in Protected Areas: Guidelines for Planning and Management.- IUCN, pp. 183, Glad.

Fernandes, A., 2007: Fitogeografia Brasileira.- Multigraf Editora, pp. 183, Fortaleza.

Gillieson, D.S., 2011: Management of caves.- In: van Beynen, Philip E. (ed.) Karst management. Springer, pp. 141-158, Tampa.

Hildreth-Werker V. \& J. Werker, 2006: Cave restoration overview - why call it cave restoration?- In: Hildreth-Werker, V. \& Werker, J.C. (Eds.) Cave Conservation and Restoration. National Speleological Society, pp. 293-302, Huntsville.

Instituo Ekos Brasil., n.d.: Projeto Detalhador Implantação do Parque Nacional Cavernas do Peruaçu.

Kalikoski, D.C., Seixas, C. S. \& T. Amuldi, 2009. Gestão compartilhada e comunitária da pesca no Brasil: avanços e desafios.- Ambiente \& Sociedade, 1, 151172.

Leung, Y.-F., Spenceley, A., Hvenegaard, G., \& R. Buckley (eds.), 2018: Tourism and visitor management in protected areas: Guidelines for sustainability.- IUCN, pp. 120, Gland.

Lima, G.; Ribeiro, G.; \& W. Gonçalves, 2005: Avaliação da efetividade de manejo das unidades de conservação de proteção integral em Minas Gerais.- Revista Árvore, 29, 647-653. http://dx.doi.org/10.1590/ S0100-67622005000400017

Lobo, H.A.; P. Boggiani, 2013: Cavernas como patrimônio geológico.- Boletim Paranaense de Geociências, 70, 190-199.

Marino, D., \& D. Pellegrino, 2018: Can Payments for Ecosystem Services Improve the Management of Natura 2000 Sites? A Contribution to Explore Their Role in Italy.- Sustainability, 10, 1-19.

Medeiros, R., Irving, M. \& I. Garay, 2004: A Proteção da Natureza no Brasil: evolução e conflitos de um modelo em construção.- Revista de Desenvolvimento Econômico, 9, pp. 83-93.

Medeiros, R., 2006: Evolução das tipologias e categorias de áreas protegidas no Brasil.- Ambiente \& Sociedade, 9, 41-64. http://dx.doi.org/10.1590/S1414$-753 X 2006000100003$

Mungai, M. F., 2008: Mosaico de interesses, representações e conflitos: o Parque Nacional Cavernas do Peruaçu- 
-MG.- MSc Thesis. Universidade Federal de Minas Gerais, pp. 183.

Myers, N., Mittermeier, R. A., Mittermeier, C. G., Da Fonseca, G. A., \& J. Kent, 2000: Biodiversity hotspots for conservation priorities.- Nature, 403, 853-858.

Oliveira, U., Soares-Filho, B. S., Paglia, A. P., Brescovit, A. D., Carvalho, C. J., Silva, D. P., ... \& J. R. Stehmann, 2017: Biodiversity conservation gaps in the Brazilian protected areas.- Scientific reports, 7, 1-9. DOI:10.1038/s41598-017-08707-2

Pellin, A., Tachard, A. L., Silva, L. F. \& V. E. Ranieri, 2007: Compensação ambiental como fonte de recursos para unidades de conservação: situação atual e aspectos polêmicos.- OLAM-Ciência \& Tecnologia, 7, 171-186.

Pegas, F. D. V., \& J. G. Castley, 2014: Ecotourism as a conservation tool and its adoption by private protected areas in Brazil.- Journal of Sustainable Tourism, 22, 604-625. https://doi.org/10.1080/09669582.2013.87 5550

Piló, L. B.; E. Rubbioli, 2002: Cavernas do Vale do Rio Peruaçu (Januária e Itacarambi), MG: Obra-prima de carste brasileiro.- In: C. Schobbenhaus; D.A. Campos; E. T. Queiroz; M. Winge \& M. Berbert-Born (eds.) Sítios geológicos e paleontológicos do Brasil. DNPM/CPRM, pp.453-460, Brasília.

Piló, L. B., 1998: Morfologia cárstica e materiais constituintes: dinâmica e evolução da depressão poligonal Macacos-Baú, Carste de Lagoa Santa, MG.- PhD thesis. Universidade de São Paulo.

Piló, L. B., 1997: Caracterização regional do carste do vale do rio Peruaçu.- O Carste, 9, 22-29.

Piranha, J. M., Del Lama, E. A., \& D. D. Bacci, 2011: Geoparks in Brazil - strategy of geoconservation and development.- Geoheritage, 3, 289-298.

Pfueller, S. L., Lee, D., \& J. Laing, 2011: Tourism partnerships in protected areas: exploring contributions to sustainability.- Environmental management, 48, 734-749. DOI 10.1007/s00267-011-9728-y

Ramus, C. A., \& I. Montiel, 2005: When are corporate environmental policies a form of greenwashing?Business \& Society, 44, 377-414.

Rocktaeschel, B. M., 2006: Terceirização em áreas protegidas: estímulo ao ecoturismo no Brasil. Senac, pp. 134.

Rylands, A. B. \& K. Brandon, 2005: Unidades de Conservação brasileiras.- Megadiversidade, 1, 27-35.

Saporiti, N., 2006: Managing national parks: How public-private partnerships can aid conservation. The World Bank Group Private Sector Development Vice Presidency Note Number 309.- [Online] Available from http://siteresources.worldbank.org/
EXTFINANCIALSECTOR/Resources/282884130 3327122200/309Saporiti.pdf [Accessed 19th January 2019].

Serafini, S., 2005: Delimitação de unidades climáticas locais no parque nacional Cavernas do Peruaçu. - $\mathrm{PhD}$ thesis. Universidade de São Paulo, pp. 155.

Silva, C. R., 2008: Geodiversidade do Brasil: conhecer o passado, para entender o presente e prever o futuro. CPRM, pp. 264, Rio de Janeiro.

Sousa, N., Santos, F. Salgado, M. \& F. Araújo, 2011: Dez anos de história: Avanços e desafios dos Sistema Nacional de Unidades de Conservação.- In: Medeiros, R.; F. Araújo (Orgs.) Dez anos do Sistema Nacional de Unidades de Conservação da Natureza: lições do passado, realizações presentes e perspectivas para o futuro. Ministério do Meio Ambiente, pp. 7-20, Brasília.

Spenceley, A., Snyman, S. \& P. Eagles, 2017: Guidelines for Tourism Partnerships and Concessions for Protected Areas: Generating Sustainable Revenues for Conservation and Development. Report to the Secretariat of the Convention on Biological Diversity and IUCN.[Online] Available from https://www.cbd.int/tourism/doc/tourism-partnerships-protected-areasprint.pdf [Accessed 15th January 2019].

Travassos, L. E. P. \& H. C. Kohler, 2009: Historical and geomorphological characterization of a Brazilian karst region.- Acta Carstologica, 38, 277-291.

Watson, J. E., Dudley, N., Segan, D. B., \& M. Hockings, 2014: The performance and potential of protected areas.- Nature, 515, 67-73.

Whitelaw, P. A., King, B. E., \& D. Tolkach, 2014: Protected areas, conservation and tourism-financing the sustainable dream.- Journal of Sustainable Tourism, 22, 584-603.

Williams, P., 2008: World heritage caves and karst.IUCN, pp. 34, Gland.

Wilson, E., Nielsen, N., \& J. Buultjens, 2009: From lessees to partners: exploring tourism public-private partnerships within the New South Wales national parks and wildlife service.- Journal of Sustainable Tourism, 17, 269-285.

Wyman, M., Barborak, J.R., Inamdar, N. \& T. Stein, 2011: Best Practices for Tourism Concessions in Protected Areas: A Review of the Field.- Forests, 2, 913-928.

WWF-BRASIL \& ICMBIO, 2012: Efetividade de gestão das Unidades de Conservação do Federais do Brasil: resultados de 2010. WWF-BRASIL \& ICMBIO, pp. 67, Brasília. 